University of Nebraska - Lincoln

DigitalCommons@University of Nebraska - Lincoln

Panhandle Research and Extension Center

Agricultural Research Division of IANR

1980

\title{
Wheat Straw in Growing Cattle Diets
}

\author{
Gary Lesoing \\ University of Nebraska-Lincoln, glesoing2@unl.edu \\ Ivan G. Rush \\ University of Nebraska-Lincoln, irush1@unl.edu \\ Terry Klopfenstein \\ University of Nebraska-Lincoln, tklopfenstein1@unl.edu \\ John Ward
}

Follow this and additional works at: https://digitalcommons.unl.edu/panhandleresext

Part of the Agriculture Commons

Lesoing, Gary; Rush, Ivan G.; Klopfenstein, Terry; and Ward, John, "Wheat Straw in Growing Cattle Diets" (1980). Panhandle Research and Extension Center. 18.

https://digitalcommons.unl.edu/panhandleresext/18

This Article is brought to you for free and open access by the Agricultural Research Division of IANR at DigitalCommons@University of Nebraska - Lincoln. It has been accepted for inclusion in Panhandle Research and Extension Center by an authorized administrator of DigitalCommons@University of Nebraska - Lincoln. 


\title{
WHEAT STRAW IN GROWING CATTLE DIETS ${ }^{1}$
}

\author{
Gary Lesoing ${ }^{2}$, Ivan Rush ${ }^{3}$, Terry Klopfenstein and John Ward \\ University of Nebraska ${ }^{4}$, Lincoln 68583
}

\begin{abstract}
Summary
Three cattle growth trials were conducted to evaluate the use of untreated and alkali-treated wheat straw as energy sources for ruminants. In trial 1, daily gain decreased as level of untreated wheat straw increased in the diet. A $14 \%$ decrease in gain occurred when the level of straw was increased from 30 to $40 \%$ of the diet. In trial 2 , cattle fed $4 \% \mathrm{NaOH}$-treated wheat straw at the 30 or $60 \%$ level had better daily gains and feed efficiencies $(\mathrm{P}<.05)$ than those fed untreated wheat straw. In trial 3, when the effect of balancing for specific mineral ratios on the alkali-treated straw diets was evaluated, steers fed $78 \%$ treated wheat straw with added minerals gained faster $(\mathrm{P}<.05)$ than those receiving $80 \%$ treated wheat straw with no mineral additions $(.65 \mathrm{~kg} / \mathrm{day}$ vs. $.54 \mathrm{~kg} / \mathrm{day})$. In addition, in this trial, cattle fed $50 \%$ treated wheat straw gained faster $(\mathrm{P}<.05)$ than those fed $50 \%$ untreated wheat straw $(.74 \mathrm{~kg} /$ day $v$ s. $.62 \mathrm{~kg} /$ day).
\end{abstract}

(Key Words: Wheat Straw, Sodium HydroxideTreated Straw.)

\section{Introduction}

Each year approximately, 229.5 million ha of wheat are grown worldwide. After the grain is harvested, much of the straw is left in the field. Wheat straw may be used as an ingredient in cattle growing diets to help producers attain maximum utilization from their higher quality feedstuffs. The relatively low available energy value of wheat straw has restricted its use to gestating beef cow diets (Arnett and McChord, 1927; Dinusson, 1969) or as a roughage source for finishing cattle (Thomas and Jordan, 1957). Use of the wheat straw in growing calf diets has

\footnotetext{
${ }^{1}$ Published with the approval of the Director as paper no. 5567 Journal Series, Nebraska Agr. Exp. Sta.

${ }^{2}$ Present address: Exp. Sta.

${ }^{3}$ Panhandle Station, Scottsbluff, NE 69361.

${ }^{4}$ Dept. of Anim. Sci.
}

been minimal because calves cannot consume enough straw to meet their energy needs. For wheat straw to be more fully utilized, its energy availability must be improved. Treatment with sodium hydroxide $(\mathrm{NaOH})$ has been effective in increasing the digestibility of cereal grain straws (Ololade et al., 1970; Klopfenstein and Woods, 1970; Rexen and Thomsen, 1976). Singh and Jackson (1971) reported an increase in digestible organic matter intake when cattle were fed $3.3 \% \mathrm{NaOH}$-treated wheat straw rather than untreated straw. This increase in digestible organic matter intake should improve rate of gain. Lambs fed $4 \% \mathrm{NaOH}$-treated wheat straw gained faster and more efficiently than those fed untreated wheat straw (Hasimoglu, 1972). While treated and untreated wheat straw have been compared in cattle digestion and intake trials and lamb growth trials, little research has been conducted to evaluate the inclusion of wheat straw in cattle growing diets.

\section{Experimental Procedure}

Three cattle growth trials were conducted to evaluate wheat straw as a component of cattle growing diets. In trial 1 , one hundred steers (average weight $242 \mathrm{~kg}$ ) were randomly allotted to five treatments (two pens per treatment) in this 81-day trial. Cattle were group-fed in outside pens with round bottom concrete feed bunks. Untreated wheat straw was ground through a $7-\mathrm{cm}$ screen and fed as: (1) 0 , (2) 10 , (3) 20 , (4) 30 or (5) $40 \%$ of the diet dry matter. The remainder of the diet consisted of corn silage, soybean meal, dicalcium phosphate and limestone (table 1). Diets were formulated to contain $11.5 \%$ crude protein, $.4 \% \mathrm{Ca}$ and $.3 \%$ $P$. The diets were fed ad libitum, and trace mineralized salt blocks were provided at all times. Vitamin A was fed once weekly to meet the animal's requirements $(2,200 \mathrm{IU} / \mathrm{kg}$ diet $)$. Samples of wheat straw, corn silage and soy'zean meal were collected weekly for dry matter determination for monitoring of feed intake. Dry matter determinations were made by 
TABLE 1. COMPOSITION OF DIETS FOR CATTLE GROWTH TRIAL $1^{\text {a }}$

\begin{tabular}{|c|c|c|c|c|c|c|}
\hline \multirow[b]{2}{*}{ Ingredient } & \multirow{2}{*}{$\begin{array}{c}\text { Internat'l. } \\
\text { Ref. No. }\end{array}$} & \multicolumn{5}{|c|}{ Wheat straw level } \\
\hline & & $0 \%$ & $10 \%$ & $20 \%$ & $30 \%$ & $40 \%$ \\
\hline Wheat straw & $1-05-175$ & 0 & 10 & 20 & 30 & 40 \\
\hline Corn silage & 3-08-154 & 91.19 & 80.02 & 68.86 & 57.69 & 46.52 \\
\hline Soybean meal & 5-04-604 & 8.53 & 9.64 & 10.74 & 11.84 & 12.94 \\
\hline Dicalcium phosphate & $6-01-080$ & .19 & .24 & .30 & .35 & .41 \\
\hline Limestone & 6-01-069 & .09 & .10 & .11 & .12 & .13 \\
\hline
\end{tabular}

${ }^{a}$ Dry matter basis.

drying samples in a forced air oven $(60 \mathrm{C})$ to a constant weight. Calves were weighed at the outset of the trial after a 16-hr shrink without feed and water. At the conclusion of the trial, calves were weighed full, with their final weight adjusted by applying a $4 \%$ shrink.

In trial 2, treated and untreated wheat straw was fed at three different levels in growing diets. One hundred steers (average weight $298 \mathrm{~kg}$ ) were randomly allotted to five treatments (two pens per treatment) in this 114-day trial. Cattle were again group-fed in outside pens with round bottom concrete feed bunks. The diets offered were: (1) corn silage- $0 \%$ wheat straw, (2) corn silage-30\% untreated wheat straw, (3) corn silage- $60 \%$ untreated wheat straw, (4) corn silage- $30 \%$ treated wheat straw and (5) corn silage- $60 \%$ treated wheat straw. Diets were formulated to contain $11.5 \%$ crude protein, $.4 \% \mathrm{Ca}$ and $.3 \% \mathrm{P}$, with corn silage, soybean meal and dicalcium phosphate provided in addition to the wheat straw (table 2). Salt, trace minerals and vitamin $A$ were provided as in trial 1, diets were again fed ad libitum. The wheat straw used in the trial was ground as in trial 1. Approximately one-half of the ground wheat straw was then chemically treated with $4 \% \mathrm{NaOH}$ ( $4 \mathrm{~kg}$ of $\mathrm{NaOH} / 100 \mathrm{~kg}$ of wheat straw dry matter) by the method described by Waller (1976). A $20 \% \mathrm{NaOH}$ solution and enough water to increase the moisture content of the wheat straw to $60 \%$ were applied. The straw was then mixed, packed into a bunker silo and allowed to react for a minimum of 5 days before feeding. Black vinyl plastic was used to cover the wheat straw to help prevent spoiling and drying.

Dry matter was monitored as in trial 1. In vitro dry matter disappearance (IVDMD) was determined on wheat straw samples for purposes of comparing treated and untreated wheat straw; determinations were made by the twostage digestion technique described by Tilley and Terry (1963). Calves were weighed initially after a 16-hr shrink without feed and water. On the 110 th day of the trial, cattle were removed from their treatments and fed equal amounts of a standard corn silage and soybean meal diet for 4 days. They were then weighed after a $16-\mathrm{hr}$ shrink.

In trial 3, treated and untreated wheat straw, with minerals added to some of the treated straw diets to balance for high sodium intake, were fed in growing steer diets. One hundred and twenty steers (average weight $201 \mathrm{~kg}$ ) were randomly allotted to five treatments (two pens per treatment) in this 109-day growth trial. Steers were group-fed in outside pens with square bottom concrete feed bunks. The steers were fed: (1) $0 \%$ wheat straw, (2) $50 \%$ untreated wheat straw, (3) $50 \%$ treated wheat straw plus mineral additions, (4) $80 \%$ treated wheat straw with no mineral additions or (5) $78 \%$ treated wheat straw plus mineral additions. Diets were formulated to contain $11.5 \%$ crude protein and at least the minimum mineral requirements (table 3). On the basis of data reported by Mosely and Jones (1974), the diets with mineral additions were balanced to the following mineral ratios: $\mathrm{Na}: \mathrm{K}, 1: 1 ; \mathrm{Na}: \mathrm{Cl}, 1.7: 1 ; \mathrm{Na}: \mathrm{Ca}$, $2: 1$, and $\mathrm{Na}: \mathrm{Mg}, 6: 1$. These ratios were used to provide a more favorable mineral balance for the steers fed the chemically-treated wheat straw diets. All diets were fed ad libitum, and trace mineralized salt was provided free choice to animals fed the treatments with no mineral additions. Vitamin A was fed once weekly to all cattle to meet their requirements. Wheat straw was ground, treated and fed as in trial 2, with the chemical treatment $3.15 \% \mathrm{NaOH}$ and $1.19 \%$ potassium hydroxide $(\mathrm{KOH})$. Dry matter and IVDMD were monitored as in trial 2. Cattle 
TABLE 2. COMPOSITION OF DIETS FOR CATTLE GROWTH TRIAL $2^{\text {a }}$

\begin{tabular}{|c|c|c|c|c|c|c|}
\hline \multirow[b]{2}{*}{ Ingredient } & \multirow{2}{*}{$\begin{array}{c}\text { Internat'l. } \\
\text { Ref. No. }\end{array}$} & \multicolumn{5}{|c|}{ Wheat straw level } \\
\hline & & $0 \%$ & $30 \%$ & $60 \%$ & $30 \%$ & $60 \%$ \\
\hline Wheat straw & $1-05-175$ & 0 & 30 & 60 & 0 & 0 \\
\hline $\mathrm{NaOH}$-treated wheat straw ${ }^{\mathrm{b}}$ & & $\mathbf{0}$ & 0 & 0 & 30 & 60 \\
\hline Corn silage & 3-08-154 & 91.14 & 57.60 & 24.08 & 57.60 & 24.08 \\
\hline Soybean meal & $5-04-604$ & 8.53 & 11.84 & 15.15 & 11.84 & 15.15 \\
\hline Dicalcium phosphate & $6-01-080$ & .34 & .56 & .77 & .56 & .77 \\
\hline
\end{tabular}

${ }^{\mathrm{a}}$ Dry matter basis.

${ }^{\mathrm{b}}$ Wheat straw was treated with $4 \mathrm{~kg} \mathrm{NaOH} / 100 \mathrm{~kg}$ of dry matter.

were weighed at the outset after a 16-hr shrink without food and water. On the $103 \mathrm{rd}$ day of the trial, cattle were taken off their treatments and fed equal amounts of a standard corn silage and soybean meal diet for 6 days. They were then weighed after a 16-hr shrink without food and water.

Individual gain and pen intake and feed efficiency data from trials 1,2 and 3 were analyzed by analyses of variance as described by Steel and Torrie (1960). Orthogonal comparisons were conducted to evaluate treatment mean differences. Comparisons made were: 1 vs $2,3,4,5 ; 2,3$ vs 4,$5 ; 2$ vs 3 , and 4 vs 5 .

\section{Results and Discussion}

In trial 1 , as the level of straw in the diet increased, average daily gain decreased (table 4). This finding agrees with a report by Forbes et al. (1969) in which increasing levels of barley straw in cattle diets decreased average daily gain. As expected, cattle fed a diet of corn silage and soybean meal gained significantly faster and more efficiently than those fed wheat straw. The decrease in daily gain was particularly evident at the $40 \%$ straw level. Steers fed $30 \%$ wheat straw gained $.11 \mathrm{~kg} /$ day faster than those receiving $40 \%$ straw. Although feed intakes were not significantly different, intake was highest for steers fed the $30 \%$ wheat straw diet. These data suggest that wheat straw stimulates intake up to a certain point, but that at higher levels, it depresses intake. Kay et al. (1970) found that dry matter intake increased when barley straw was included as $35 \%$ of a

TABLE 3. COMPOSITION OF DIETS FOR CATTLE GROWTH TRIAL $3^{\text {a }}$

\begin{tabular}{|c|c|c|c|c|c|c|}
\hline \multirow[b]{2}{*}{ Ingredient } & \multirow{2}{*}{$\begin{array}{l}\text { Internat'l. } \\
\text { Ref. No. }\end{array}$} & \multicolumn{5}{|c|}{ Wheat straw level } \\
\hline & & $0 \%$ & $50 \%$ & $50 \% \mathrm{~b}$ & $80 \%$ & $78 \%^{b}$ \\
\hline Wheat straw & $1-05-175$ & 0 & 50 & 0 & o & $\mathbf{0}$ \\
\hline $\mathrm{NaOH}$-treated wheat straw ${ }^{\mathrm{c}}$ & & 0 & 0 & 50 & 79.81 & 78.22 \\
\hline Corn silage & 3-08-154 & 91.13 & 34.02 & 33.32 & 0 & $\mathbf{0}$ \\
\hline Soybean meal & $5-04-604$ & 8.53 & 15.27 & 15.47 & 19.28 & 19.36 \\
\hline Calcium chloride & & 0 & 0 & .29 & 0 & 1.17 \\
\hline Dicalcium phosphate & $6-01-080$ & .34 & .71 & .98 & .91 & 1.03 \\
\hline Magnesium oxide & $6-02-757$ & 0 & 0 & .04 & 0 & .22 \\
\hline Trace mineral ${ }^{\mathrm{d}}$ & & 0 & 0 & .05 & 0 & .05 \\
\hline
\end{tabular}

\footnotetext{
${ }^{a}$ Dry matter basis.

$b_{\text {Plus mineral additions. }}$

${ }^{c_{W h}}$ at straw was treated with $3.15 \mathrm{~kg} \mathrm{NaOH}$ and $1.19 \mathrm{~kg} \mathrm{KOH} / 100 \mathrm{~kg} \mathrm{dry}$ matter.

${ }^{\mathrm{d}}$ Composition of the trace mineral mix: $7 \% \mathrm{Mn}, .2 \% \mathrm{I}, 1 \% \mathrm{Cu}, .1 \% \mathrm{Co}, 8 \% \mathrm{Zn}, 10 \% \mathrm{Fe}, 7 \% \mathrm{Mg}$ and $15 \% \mathrm{Ca}$.
} 
TABLE 4. PERFORMANCE OF STEERS IN GROWTH TRIAL $1^{\text {a }}$

\begin{tabular}{|c|c|c|c|c|c|c|}
\hline \multirow[b]{2}{*}{ Item } & \multicolumn{6}{|c|}{ Treatment } \\
\hline & $\begin{array}{c}1 \\
0 \% \text { wheat } \\
\text { straw }\end{array}$ & $\begin{array}{c}2 \\
10 \% \text { wheat } \\
\text { straw }\end{array}$ & $\begin{array}{c}3 \\
20 \% \text { wheat } \\
\text { straw }\end{array}$ & $\begin{array}{c}4 \\
30 \% \text { wheat } \\
\text { straw }\end{array}$ & $\begin{array}{c}5 \\
\begin{array}{c}50 \% \text { wheat } \\
\text { straw }\end{array}\end{array}$ & $\begin{array}{c}\text { Standard } \\
\text { error }\end{array}$ \\
\hline No. of steers & 20 & 20 & 20 & 20 & 20 & \\
\hline Initial wt $\mathrm{kg}$ & 240.9 & 243.6 & 243.2 & 246.4 & 237.3 & \\
\hline Daily gain, kgb,c & 1.13 & .97 & .91 & .88 & .77 & .026 \\
\hline Daily intake $\mathrm{kg}$ & 8.02 & 7.59 & 8.20 & 8.49 & 7.21 & .62 \\
\hline Feed conversion $b, d$ & 7.29 & 7.73 & 8.89 & 9.53 & 9.52 & .23 \\
\hline
\end{tabular}

\footnotetext{
${ }^{a}$ (Two pens/treatment); 81 days; least-square means adjusted for pen, treatment breed with initial weight used as a covariant.

${ }^{b}$ Treatment differences $(P<.05)(1$ vs $2,3,4,5) ;(2,3$ vs 4,5$)$.

$c_{\text {Treatment differences }}(\mathrm{P}<.05)(4$ vs 5$)$.

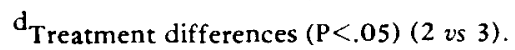

cattle growing diet but decreased at the $50 \%$ level. The increase in intake observed at the $30 \%$ level in trial 1 did not increase average daily gain. Diets containing wheat straw at the 10 and $20 \%$ levels were utilized significantly more efficiently than were those with straw at the 30 or $40 \%$ level.

Trial 2 evaluated treated and untreated wheat straw fed as 30 or $60 \%$ of the diet dry matter. As level of straw increased in the diets, average daily gain decreased (table 5). As in trial 1 , steers receiving no wheat straw gained significantly faster and more efficiently than steers that were fed straw. Chemical treatment of wheat straw with $4 \% \mathrm{NaOH}$ tended to improve average daily gain of cattle at both straw levels. Steers fed 30 and $60 \%$ chemically treated wheat straw gained 11 and $25 \%$ faster than those fed 30 and $60 \%$ untreated wheat straw, respectively. As in trial 1 , the $30 \%$ wheat straw diets were consumed in the greatest quantities.

Feed efficiencies were also affected by chemical treatment and level of untreated straw in the diet. Steers fed 30 or $60 \%$ treated wheat straw were significantly more efficient than those fed untreated straw at the same levels. Untreated wheat straw fed as $60 \%$ of the diet

TABLE 5. PERFORMANCE OF STEERS IN GROWTH TRIAL $2^{\text {a }}$

\begin{tabular}{|c|c|c|c|c|c|c|}
\hline \multirow[b]{2}{*}{ Item } & \multicolumn{6}{|c|}{ Treatment } \\
\hline & $\begin{array}{c}1 \\
0 \% \text { wheat } \\
\text { straw }^{b}\end{array}$ & $\begin{array}{c}2 \\
30 \% \text { wheat } \\
\text { stra w }^{b}\end{array}$ & $\begin{array}{c}3 \\
\underset{\text { straw }^{b}}{60 \%} \text { wheat }\end{array}$ & $\begin{array}{c}4 \\
30 \% \text { treated } \\
\text { wheat straw }\end{array}$ & $\begin{array}{c}5 \\
60 \% \text { treated } \\
\text { wheat straw }\end{array}$ & $\begin{array}{l}\text { Standard } \\
\text { error }\end{array}$ \\
\hline No. of steers & 20 & 19 & 20 & 20 & 20 & \\
\hline Initial wt, $\mathrm{kg}$ & 296.8 & 300.5 & 302.7 & 294.5 & 297.3 & \\
\hline Daily gain $\mathrm{kg}^{\mathrm{c}}$ & .97 & .73 & .52 & .81 & .65 & .11 \\
\hline Daily intake, $\mathrm{kg}$ & 9.97 & 11.15 & 9.74 & 11.96 & 9.61 & 1.95 \\
\hline Feed conversion $\mathrm{c}, \mathrm{d}$ & 10.40 & 15.29 & 18.54 & 14.97 & 14.88 & 1.84 \\
\hline
\end{tabular}

\footnotetext{
${ }^{a}$ (Two pens / treatment); 114 days, least-squares means adjusted for pen, treatment with initial weight used as a covariant.

b IVDMD of $4 \% \mathrm{NaOH}$-treated wheat straw and untreated wheat straw used in the growth trial were 57.42 and $41.56 \%$, respectively.

$\mathrm{C}_{\text {Treatment differences }}(\mathrm{P}<.05)(1$ vs $2,3,4,5 ; 2$ vs 3$)$.

$\mathrm{d}_{\text {Treatment differences }}(P<.05)(2,3$ vs 4,5$)$.
} 
induced significantly poorer feed efficiency than did the $30 \%$ untreated straw diet. Observations throughout the trial indicated some of this difference may have been due to a large amount of waste on the $60 \%$ untreated straw diet. Some of this difference can be reduced by feeding twice daily and using square bottom bunks. A problem that developed with the feeding of the $\mathrm{NaOH}$-treated straw diets was muddy lots, which was caused by high water intakes and high urine outputs induced by the high sodium content of the diets. This is a problem that producers must be aware of if they are to feed treated wheat straw, and management decisions should be made accordingly.

Two important factors were noted from trial 2. First, the cattle might have been too heavy to utilize this type of high roughage diet effectively. Second, animals fed the treated straw diets outperformed those fed the untreated straw diets early in the trial by much more than they did near the conclusion. This may have been due to a mineral imbalance in the animals consuming the $\mathrm{NaOH}$-treated straw. Mosely and Jones (1974) reported that high $\mathrm{Na}$ levels decreased retention of $\mathrm{Na}, \mathrm{K}, \mathrm{Mg}, \mathrm{P}$ and $\mathrm{N}$ and increased excretion of these minerals and $\mathrm{Ca}$.

Trial 3 was conducted to compare treated and untreated wheat straw fed at the same rate to growing cattle and to test the effect of balancing for specific mineral ratios in treated wheat straw diets. Results indicate that average daily gain of cattle was significantly affected by level of straw in the diet, chemical treatment of wheat straw and mineral additions to treated straw diets (table 6). As in trials 1 and 2, steers receiving no wheat straw gained significantly faster and more efficiently than those receiving straw. Cattle fed $50 \%$ treated wheat straw plus mineral additions gained $19 \%$ faster than those fed the $50 \%$ untreated straw diet. Balancing for the specific mineral ratios in the $78 \%$ treated wheat straw diet, increased $(\mathrm{P}<.05)$ steer gain by $.11 \mathrm{~kg} /$ day over that obtained with the $80 \%$ treated wheat straw diet with no mineral additions. Intake was similar for cattle on all treatments. Feed efficiencies were improved by chemical treatment and balancing for minerals. Cattle fed chemically-treated wheat straw plus mineral additions as $50 \%$ of the diet utilized feed $14.7 \%$ more efficiently than animals fed untreated wheat straw at the same rate. Balancing for minerals in the $78 \%$ treated wheat strà diet improved feed efficiency by $14 \%$ over the $80 \%$ treated straw diet. In trial 2 , feed efficiencies at the $30 \%$ wheat straw levels were virtually the same for animals fed untreated and treated wheat straw. Much of the difference in feed efficiencies between the untreated and treated wheat straw diets at the $60 \%$ level was due to waste of untreated straw. In trial 3, waste was not a problem and efficiencies were improved, possibly because of balancing for the specific mineral ratios.

TABLE 6. PERFORMANCE OF STEERS IN GROWTH TRIAL $3^{\text {a }}$

\begin{tabular}{|c|c|c|c|c|c|c|}
\hline \multirow[b]{2}{*}{ Item } & \multicolumn{6}{|c|}{ Treatment } \\
\hline & $\begin{array}{c}1 \\
0 \% \text { wheat }^{b} \\
\text { straw }\end{array}$ & $\begin{array}{c}2 \\
50 \% \text { wheat } \\
\text { straw }\end{array}$ & $\begin{array}{c}3 \\
50 \% \text { treated } \\
\text { wheat straw } \\
+ \text { minerals }\end{array}$ & $\begin{array}{c}4 \\
80 \% \text { treated } \\
\text { wheat straw }^{b}\end{array}$ & $\begin{array}{l}5 \\
78 \% \text { treated } \\
\text { wheat straw } b \\
+ \text { minerals }\end{array}$ & $\begin{array}{l}\text { Standard } \\
\text { error }\end{array}$ \\
\hline No. of steers & 24 & 24 & 24 & 24 & 24 & \\
\hline Initial wt, $\mathrm{kg}$ & 202.3 & 200.9 & 196.8 & 200.5 & 204.5 & \\
\hline Daily gain, $\mathbf{k g}^{\mathrm{c}, \mathrm{d}}$ & 1.05 & .62 & .74 & .54 & .65 & .018 \\
\hline Daily intake, $\mathrm{kg}$ & 6.14 & 5.53 & 5.83 & 5.32 & 5.51 & .76 \\
\hline Feed conversion $c$ & 5.86 & 9.10 & 7.76 & 9.93 & 8.54 & .32 \\
\hline
\end{tabular}

\footnotetext{
${ }^{a}$ (Two pens /treatment); 109 days, least-squares means adjusted for pen, treatment, breed with initial weight used as a covariant.

${ }^{b}$ IVDMD of $3.15 \% \mathrm{NaOH}: 1.19 \mathrm{KOH}$-treated wheat straw and untreated wheat straw used in the growth trial were 68.69 and $49.31 \%$, respectively.

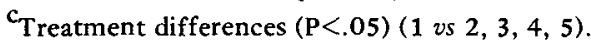

$\mathrm{d}_{\text {Treatment differences }}(\mathrm{P}<.05)(2,3$ vs 4,$5 ; 2$ vs $3 ; 4$ vs 5$)$.
} 
Results of the three cattle growth trials show the relative merits of using untreated or treated wheat straw in growing diets. Maximum utilization was obtained when treated wheat straw was fed alone with a protein source and minerals. While addition of minerals improved performance of cattle fed the treated straw diets, the effect was not clearly understood. Although chemical treatment appears promising, more research and technology is needed before it will become an economically feasible practice. Price and availability of grain, protein source and higher quality forage sources will determine the extent to which wheat straw will be employed in ruminant diets in the future.

\section{Literature Cited}

Arnett, C. N. and R. C. McChord. 1927. Winter feeding beef breeding cows. Univ. of Montana Agr. Exp. Sta. Bull. No. 211.

Dinusson, W. E. 1969. Wintering beef cows on hay or straw. 70th Annu. Livestock Roundup. Dickinson Exp. Sta. North Dakota State Univ., Dickinson.

Forbes, T. J., J.H.D. Irwin and A. M. Raven. 1969. The use of coarsely chopped barley straw in high concentrate diets for beef cattle. J. Agr. Sci. (Camb.) 73:347.

Hasimoglu, S. 1972. Evaluation of chemical treatment of low quality roughages for ruminants. Ph.D. Thesis, Univ of Nebraska, Lincoln.

Kay, M., A. MacDearmid and N. A. MacLeod. 1970.
Intensive beef production. 10. Replacement of cereals with chopped straw. Anim. Prod. 12:261.

Klopfenstein, T. and W. Woods. 1970. Sodium and potassium hydroxide treatment of wheat straw and corn cobs. J. Anim. Sci. 31:246.

Moseley, G, and D.I.H. Jones. 1974. The effect of sodium chloride supplementation of a sodium adequate hay on digestion, production and mineral nutrition in sheep. J. Agr. Sci. (Camb.) $83: 37$.

Ololade, B. G., D. N. Mowat and J. E. Winch. 1970. Effect of processing methods on the in vitro digestibility of sodium hydroxide treated roughages. Can. J. Anim. Sci. 50:657.

Rexen, F. and K. Vestergaard Thomsen. 1976. The effect on digestibility of a new technique for alkali treatment of straw. Anim. Feed Sci. Technol. 1:73.

Singh, Mahendra and M. G. Jackson. 1971. The effect of different levels of sodium hydroxide spray treatment of wheat straw on consumption and digestibility by cattle. J. Agr. Sci. (Camb.) 77:5.

Steel, R.G.D. and J. H. Torrie. 1960. Principles and Procedures of Statistics. McGraw Hill Book Co., New York.

Thomas, O. O. and Harley Jordan. 1957. Utilization of straw in cattle fattening rations. Progress Report. Project M.S, 1005 Agr. Exp. Sta., Sept. Mont. State College, Anim. Ind. Dep. A.I. Leaflet No. 8.

Tilley, J.M.A. and R. A. Terry. 1963. A two-state technique for the in vitro digestion of forage crops. J. Brit. Grassl. Soc. 18:104.

Waller, J. C. 1976. Evaluation of sodium, calcium and ammonium hydroxides for treating crop residues. M.S. Thesis. Univ. of Nebraska, Lincoln. 